\title{
The Effect of Asset Use Activities on Capital Structure, Business Risk, Financial Performance and Corporate Value (Study of Manufacturing Industry Companies in the Indonesia Stock Exchange)
}

\author{
Ari Data \\ Economic Education Study Program, Faculty of Teacher Training and Education, Nusa Cendana University \\ Adisucipto Street, Penfui Kupang City, East Nusa Tenggara Indonesia
}

\begin{abstract}
This study aims to examine and explain the effect of the asset usage activities on the capital structure, business risk, financial performance and corporate value. Test and explain the effect of capital structure on the business risk, financial performance and corporate value. Test and explain the effect of the business risk on the financial performance and corporate value. Test and explain the effect of the financial performance on corporate value. Analysis techniques, using the generalized structured component analysis (GSCA). Data sampled 84 companies listed in Indonesia Stock Exchange in 2010 - 2015. The findings of this study is the asset usage activities has a significant negative effect on capital structure and a significant negative effect on business risk. The asset usage activities has a significant positive effect on financial performance and corporate value. The capital structure has a significant positive effect on business risk. The capital structure has a significant negative effect on financial performance, and is significantly positive to corporate value. The business risk has a significant negative effect on financial performance and corporate value. Financial performance has a significant positive effect on corporate value. The study concludes that asset usage activities can determine the capital structure, financial performance and corporate value. Therefore, the corporate's management and financial analysts can examine the asset usage activities and capital structure, busines risk and financial performance to predict the future value of the corporate.
\end{abstract}

Keywords: Asset usage Activities, Capital Structure, Business Risk, Financial Performance, Corporate Values.

DOI: $10.7176 / \mathrm{EJBM} / 11-36-07$

Publication date: December $31^{\text {st }} 2019$

\section{Introduction}

The corporate was founded to achieve the main goal of maximizing the welfare of the owners or shareholders by increasing the value of the corporate (Keown et al., 2000: 2). The management of the corporate is entrusted by the owners to manage the corporate in hopes of obtaining profits and increasing the wealth of the owners. The corporate will use its own capital and debt together, both short-term debt and long-term debt in funding various assets that will be used in the corporate's operational activities.

The corporate's operational activities use assets that have been allocated for use. If the use of corporate assets is getting better, it can make higher sales and obtain higher profits as well (Gopal, 2009: 207). The financial manager is required to make decisions related to the use of assets and funding activities to ensure the smooth operation of the corporate. Pecking order theory (Myers and Majluf, 1984) revealed that companies that have high profits and internal cash flows can reduce the use of debt and interest costs. High profits will increase the value of the corporate.

Corporate value according to investors' perception of the corporate is often related to stock prices. Irrelevance Theory (Modigliani and Miller, 1958) explains that investment decisions and asset use activities determine financial performance and have an impact on corporate value. High asset usage activities reflect efficiency in asset management, so as to increase profitability and minimize business risk. Capital structure decisions have implications for capital costs, financial performance and corporate value. Therefore, it is interesting to study further about the activities of asset use, capital structure, business risk, financial performance and corporate value.

Starting from the thought that the suitability of investment requirements to maintain or increase asset use activities will determine the optimal capital structure, and subsequently will determine the financial performance and value of the corporate. Then it is suspected that there is a comprehensive effect on the activities of using capital structure assets, biological risk, financial performance and corporate value. Therefore, this research model was built by involving these 5 variables, and is based on theoretical studies and previous research studies.

Empirically this research is the development of previous research, namely: Kouser et al. (2012); Oluwagbemiga (2013); Omondi and Muturi (2013); Çekrezi (2013b); Adi et al. (2013); Gathogo and Ragui (2014); Asiri and Hameed (2014); Chukwunweike et al. (2014); Siahaan et al. (2014); Masoud (2014); Barakat (2014) which examines the effect of corporate growth, liquidity, business risk, capital structure and financial 
performance, on corporate value.

Where the general weakness in previous research is that previous research uses only one indicator to represent the other indicators in the measurement of variables, because the analysis tools used do not allow to analyze data on variables studied in a structured manner and the number of indicators is large (weaknesses of analytical tools used) used). Therefore, this research develops a more comprehensive concept model, by adding the number of indicators to each variable, and also adding new variables to the previous research model, and using a generalized structured component analysis (GSCA) analysis tool that is able to analyze data of the variables studied in a structured manner, and a large number of indicators.

The novelty of this research is to combine the activity variables of the use of assets as variables that affect capital structure, business risk, financial performance and corporate value, which in previous empirical studies have not been examined. Asset use activities have an important role in determining capital structure, business risk, financial performance and corporate value. Asset use activities are operational activities to generate revenue that have an impact on capital structure, minimize business risk, improve financial performance and corporate value. The originality of this research lies in providing empirical evidence of the influence of the activities of asset use, capital structure, business risk, financial performance and corporate value. It is expected to provide a deeper understanding of the important role of asset use activities to determine capital structure and business risk that have an impact on improving financial performance and corporate value.

This research was conducted at manufacturing industry companies listed on the Indonesia Stock Exchange. Manufacturing industry companies play an important role in economic development and contribute to the manufacturing industry on Indonesia's GDP. Using a sample of 84 manufacturing industry companies, with a period of time from 2010 to 2015. The source of the data comes from the Indonesia Stock Exchange database, because on the Indonesia Stock Exchange data available financial statement data audited by public accountants. The unit of analysis is 84 companies using panel data that is time series and cross-sectional, for 6 years in sequence and across industrial sub-sectors in one manufacturing industry sector. The wider the time span used, the more number of observations will be made.

\subsection{Research Problem Formulation}

1) Does the activity of using assets significantly influence capital structure, business risk, financial performance and corporate value?

2) Does the capital structure have a significant effect on business risk, financial performance and corporate value?

3) Does business risk have a significant effect on the financial performance and corporate value?

4) Does the financial performance significantly influence the value of the corporate?

\subsection{Research Purposes}

This study aims to develop a new theoretical approach as an effort to add to the capital structure literature that discusses funding policies, asset use activities that focus on improving financial performance and corporate value. This study focuses on research problems that have been formulated and proposed for further empirical study, so the objectives of this study are detailed as follows:

1) Test and explain the effect of asset use activities on capital structure, business risk, financial performance and corporate value.

2) Test and explain the effect of capital structure on business risk, financial performance and corporate value.

3) Test and explain the effect of business risk on financial performance and corporate value.

4) Test and explain the effect of financial performance on corporate value.

\section{Literature Review}

\subsection{The Effect of Asset Use Activities on Capital Structure}

Asset use activity is the use of corporate assets that have been allocated for the purpose of producing goods or services for sale to achieve the corporate's objectives. The level of activity of using assets determines the funding mechanism. The funding mechanism reflects the corporate's capital structure. Increasing the activity of using assets will reduce the debt ratio in the capital structure. The higher the asset turnover ratio means the faster the return of funds into the corporate, so that sufficient internal funds are available to be reinvested, and can reduce the use of debt.

The effect of asset use activities on capital structure, as explained by the pecking order theory (Myers and Majluf, 1984) states that companies that operate effectively and efficiently have high profits and internal returns. Companies that use their assets effectively and efficiently will reduce the use of debt to reduce debt costs. The theoretical implication of the effect of the activity of the use of assets on capital structure is that an increase in the ratio of assets use activities will reduce the capital structure. Based on this explanation, the following hypothesis is formulated: 
$\mathrm{H}_{1}$ : Asset use activities have a significant effect on capital structure.

\subsection{The Effect of Asset Use Activities on Business Risk}

Companies that use their assets effectively and efficiently will minimize business risk. Because the effectiveness and efficiency in the use of assets will speed up cash receipts, and cash received back is risk free. Companies that have large cash flows will also have the opportunity to invest in new projects that are profitable, thereby reducing the risk of losing business opportunities. The theoretical implication of the effect of the activity of using assets to business risk is an increase in the ratio of assets use activities to business risk. Based on these explanations, the following hypothesis are formulated:

$\mathrm{H}_{2}$ : Asset use activities have a significant effect on business risk.

\subsection{The Effect of Asset Use Activities on Financial Performance}

Leverage irrelevance theory (Modigliani and Miller, 1958) argues that investment decisions determine profits. The logic of investment decisions is to decide what investment is chosen, how much the investment value is, when and where the investment is carried out. After the investment is made, it will then carry out production process activities using assets that have been allocated for their use by the corporate to produce goods or services for sale and generate cash and profit receipts. Investment decisions have an impact on the activities of using assets that are effective and efficient will result in higher profits and better financial performance.

Du-Pont analysis explains the effect of activity ratios on profitability ratios (Hanafi, 2010: 51-52). Effective and efficient use of asset activities can increase profits for the corporate. High asset use activities reflect efficiency in asset management (Kamaludin and Indriani, 2012: 44).

The effectiveness of the management of corporate assets, both in current assets and fixed assets and also the structure of these assets so as to increase investment returns. The tool to measure operational effectiveness is the activity ratio (Subramanyam and Wild, 2013: 159-160). The activity ratio illustrates the level of utilization of a corporate's assets to make sales and generate profits. If the corporate uses assets more efficiently, then sales will be higher and profits will also rise. The theoretical implication of the effect of the activity of the use of assets on financial performance is an increase in the use of assets will improve financial performance. Based on this explanation, the following hypothesis is formulated:

$\mathrm{H}_{3}$ : The activity of using assets has a significant effect on financial performance.

\subsection{The Effect of Asset Use Activities on Corporate Value}

The use of asset activity will determine the amount of cash inflows in each period, and the availability of cash flows in the current period to be reinvested in the corporate's assets will determine how much additional sources of external funds. The operation of each fund embedded in the assets used effectively will produce maximum investment returns (Kamaludin and Indriani, 2012: 44).

Effect of asset use activities on corporate value. Leverage irrelevance theory (Modigliani and Miller, 1958) explains the value of a corporate is determined by the success of an investment, and the success of an investment is inseparable from the activity of using assets in the process of producing goods or services to be sold and generating revenue and profits. The resulting profit will add to the wealth of the corporate's owners. The theoretical implication of the empirical effect of the activity of the use of assets on the value of the corporate is that increasing the use of assets will increase the value of the corporate. Based on this explanation, the following hypothesis is formulated:

$\mathrm{H}_{4}$ : The activity of using assets has a significant effect on corporate value.

\subsection{The Effect of Capital Structure on Business Risk}

The corporate determines the capital structure policy will involve the choice of trade off between risk and profit, it must consider the risk to be borne by the corporate, if using more debt will increase the fixed costs to be borne by the corporate and ultimately increase the risk (Kamaludin and Indriani, 2012: 304-305). The use of high debt will increase fixed costs that have the potential to increase risk. High operating risk combined with higher financing risk will cause the corporate to fail (Myers, 1984). Abor and Biekpe (2005) argue that the more likely a corporate is to bear the costs, the greater the effort to reduce the level of debt in the capital structure, the capital structure has a positive impact on increasing corporate risk.

Previous research examining the relationship between business risk and capital structure is Oolderink (2013), Akorsu (2014) found business risk is significantly and negatively correlated to capital structure. The theoretical implication of the empirical is that increasing business risk will reduce capital structure. Research conducted by Çekrezi (2013b), Saeed et al. (2014) found that business risk is significantly and positively correlated to capital structure. The theoretical implication of the empirical is that increasing business risk will improve capital structure. Theoretical and empirical explanations so far have shown that business risk has positive and negative impacts on capital structure. Based on the previous trade off theory and empirical 
explanations, that business risk influences capital structure, but there is no research that examines the effect of capital structure on business risk, the following hypothesis is formulated:

$\mathrm{H}_{5}$ : Capital structure has a significant effect on business risk.

\subsection{The Effects of Capital Structure on Financial Performance}

Pecking order theory (Myers and Majluf, 1984) predicts a negative correlation between profitability and capital structure. High debt will increase the fixed costs of debt along with additional debt, and transaction costs, debt agency costs will force cash outflows that have a negative impact on financial performance and the probability of bankruptcy if the corporate experiences financial difficulties, supported by research findings conducted by Umar et al. (2012), Ogebe (2013), Bokhari and Khan (2013), Omondi and Muturi (2013), Pontoh and Ilat (2013), Chukwunweike et al. (2014), Marobhe (2014) found that capital structure has a significant and negative effect on financial performance.

Capital structure has an important role in determining the corporate's financial performance, as explained by the pecking order theory which states that the corporate prefers internal funding sources rather than external funding sources, because internal funds are free of charge. So companies that have large profits will reduce the use of debt and interest costs. Pecking order theory emphasizes the order in which funding preferences are of one, which is the most sensitive to others, because asymmetric information between corporate management has more information and market participants (investors and prospective investors) who lack information about the condition of assets and investment opportunities as well corporate prospects in the future (Myers and Majluf, 1984). Based on this explanation, the following hypothesis is formulated:

$\mathrm{H}_{6}$ : Capital structure has a significant effect on financial performance.

\subsection{The Effect of Capital Structure on Corporate Value}

Trade off theory, pecking order theory, and leverage signaling theory explain that capital structure has a significant positive effect on corporate value. Trade off theory (Modigliani and Miller, 1963) predicts a positive relationship between capital structure and corporate value with the assumption that tax benefits are greater than the costs of financial difficulties and agency costs, then the tax benefits of using debt will have a positive impact on corporate value (Barakat, 2014 ).

Pecking order theory (Myers and Majluf, 1984) argues that if a corporate wants to use external funding sources, it must choose debt before new equity, because debt is cheaper and less sensitive to asymmetric information, so the capital market will react positively to debt issuance and make the corporate's stock price go up. Conversely, if a corporate wants to issue new shares, the costs are higher and very sensitive to asymmetric information, so that the capital market will react negatively to the issuance of new shares, and make the corporate's stock prices go down (Ogbulu and Emeni, 2012). Leverage signaling theory (Ross (1977) argues that debt is a credible signal about the quality and prospects of the corporate in the future, so that the market will react positively to the corporate's stock price.

Research that examines the effect of capital structure on corporate value is a study conducted by Chowdhuri and Chowdhuri (2010), Ogbulu and Emeni (2012), Oluwabemiga (2013), Barakat (2014), Isaac (2014) found that capital structure has a significant and positive effect on the value of the corporate. Supporting trade off theory (Modigliani and Miller, 1963), pecking order theory (Myers and Majluf, 1984), and leverage signaling theory (Ross (1977). The theoretical implication of the empirical is to increase capital structure to a certain degree will increase corporate value.

Research findings conducted by Ghalandari (2013), Adi et al. (2013), Asiri and Hameed (2014), Siahaan et al. (2014) found that capital structure has a significant and negative effect on corporate value, does not support trade off theory (Modigliani and Miller, 1963), pecking order theory (Myers and Majluf, 1984), and leverage signaling theory (Ross (1977).

Based on theoretical and empirical explanations so far, it shows that capital structure has positive and negative impacts on corporate value. The positive impact indicates that the use of debt will encourage an increase in the value of the corporate, because there are benefits of debt greater than the cost of debt. The research findings have a negative impact indicating that the use of debt that is too high will reduce the value of the corporate, because the benefits of debt are decreasing compared to the high cost of debt. Based on this explanation, the following hypothesis is formulated:

$\mathrm{H}_{7}$ : Capital structure has a significant effect on corporate value.

\subsection{The Effect of Business Risk on Financial Performance}

Trade off theory (Modigliani and Miller, 1963) argues that business risk has a significant effect on financial performance, meaning that the higher the business risk will reduce profitability, because the increase in risk along with the increase in operational costs of the corporate will have an impact on the decline in operating income. Research conducted by Adi et al. (2013), Chukwunweike et al. (2014) found that business risk had a 
significant and negative effect on financial performance. The theoretical implication of the empirical is that increasing business risk will reduce financial performance. Based on the explanation of trade off theory (Modigliani and Miller, 1963) and earlier empiricism that business risk influences financial performance, the following hypothesis is formulated:

$\mathrm{H}_{8}$ : Business risk has a significant effect on financial performance.

\subsection{Effect of Business Risk on Corporate Value}

Leverage irrelevance theory (Modigliani and Miller, 1958) argues that the value of a corporate depends on the rate of return on investment (cash flow) and risk. "In a perfect capital market, the total value of the corporate is the same as the market value of the total cash flow generated by the assets and is not affected by the choice of capital structure", in the sense that investment decisions in assets and asset use activities will generate cash inflows (profits) that affect the financial performance and value of the corporate, as well as the risk of uncertainty generated cash flow will determine the financial performance and value of the corporate.

Research by Asiri and Hameed (2014) found that business risk has a significant and positive effect on corporate value. The empirical implication is that increasing business risk will increase the value of the corporate. This happens, if investors expect a high rate of return by raising the corporate's stock price to offset the high risk. Based on the explanation of leverage irrelevance theory (Modigliani and Miller, 1958) and the previous empirical that business risk influences corporate value, the following hypothesis is formulated:

$\mathrm{H}_{9}$ : Business risk has a significant effect on corporate value.

\subsection{The Effect of Financial Performance on Corporate Value}

The ability of the corporate to generate profits will determine the ability to provide an internal source of funds to finance the corporate's growth and dividends or capital gains that are expected to increase the wealth of the owner. Many investors are interested in buying shares of high-performing companies. The more people who will buy, the price will go up and the opposite will happen if the corporate is under-performing. Investors are less interested in companies that have low performance. Ghosh and Arijit (2008) explain that financial performance has a positive impact on corporate value. Increased profits are seen as a signal that the control and operations of the corporate are better, thereby adding to the value of equity.

Leverage irrelevance theory (Modigliani and Miller, 1958) argues that the value of a corporate is determined by the level of investment returns and business risks. Thus the productivity, efficiency, and success of an investment will be measured by profits. Profits reflect the financial performance of a significant and positive effect on the value of the corporate. Research conducted by Ghosh and Arijit (2008), Adi et al. (2013), Asiri and Hameed (2014) found that financial performance had a significant and positive effect on corporate value. The theoretical implication of the empirical is that increasing financial performance will increase corporate value. Based on this explanation, the following hypothesis is formulated:

$\mathrm{H}_{10}$ : Financial performance has a significant effect on corporate value.

\section{Research Method}

\subsection{Type of Research}

This type of research is explanatory namely to explain the effect between one or several variables with one or several other variables, using secondary data. Based on the research model developed, it is expected to be able to better explain the influence between the analyzed variables, and at the same time be able to make research implications that are useful for the development of science as well as a method for solving problems in the field.

According to Sugiyono (2014: 23) quantitative research methods are based on the philosophy of positivism, which is used to examine a particular population or sample, research data collection, quantitative or statistical data analysis, with the aim of testing hypotheses. This research is focused on empirical testing of the theory by testing the influence between variables measured and analyzed using statistical procedures for hypothesis testing.

\subsection{Research Location}

The location of this research in Indonesia and the object of observation are all manufacturing companies listed on the Indonesia Stock Exchange, with the observation period starting from 2010 to 2015.

\subsection{Research Population and Samples}

The population in this study were all manufacturing industry companies on the Indonesia Stock Exchange (IDX), with an observation period starting from 2010 to 2015 totaling 146 companies. Sampling using a purposive method that is the researcher determines certain criteria or objectives for the sample to be studied (Indriantoro and Supomo 1999: 146). This research is limited to the period 2010 to 2015 . The unit of analysis using data from 84 companies multiplied by 6 years is 504 financial statements. 


\subsection{Operational Definitions of Research Variables}

\subsubsection{Exogenous Variables Asset Use Activities (X)}

Asset use activity is the use of corporate assets that have been allocated for the purpose of producing goods or services for sale to achieve the corporate's objectives. Asset use activity variable is measured by current asset turnover (CATO), inventory turnover (ITO), receivable turnover (RTO), fixed asset turnover (FATO), total asset turnover or FATO total assets turnover (TATO). Referring to Hanafi (2010: 38-40), Kamaludin and Indriani (2012: 44-45).

Current asset turnover (CATO) is calculated as follows:

CATO $=($ Net Sales $) /($ Current asset $)$

Inventory turnover (ITO) is calculated using the following formula:

$\mathrm{ITO}=($ Net Sales $) /$ Inventory

Receivable turnover (RTO) is calculated using the following formula:

$\mathrm{RTO}=($ Net Sales $) /$ Receivable

Fixed asset turnover (FATO) is calculated using the following formula:

Fixed assets turnover $($ FATO $)=($ Net Sales $) /($ Fixed assets $)$

Total assets turnover (TATO) is calculated using the following formula:

TATO $=($ Net Sales $) /($ Total assets $)$

Activity ratio describes how much the efficiency and effectiveness of the use of assets by companies, as well as how much funds are embedded in each group of corporate assets. If the funds that are embedded in certain assets are large enough, the funds should be used for investments in other assets that are more productive, so profitability is not as good as it should be. If the corporate uses assets more efficiently, then sales will be higher and profits will also rise. Asset use activity is predicted as a determinant of capital structure, financial performance and corporate value.

\subsubsection{Endogenous Variables of Capital Structure (Y1)}

Capital structure is a combination of debt and equity in funding the assets of a corporate called leverage. Indicators of capital structure are the total debt to total assets ratio (DAR), debt to equity ratio (DER) and long term debt to equity (LTDTE). Total debt to total assets ratio (DAR) is the ratio of total liabilities to total assets. Total debt to total assets ratio (DAR) is used to measure how much the corporate's assets are financed with debt. Referring to Cekresi (2013) and Chukwunweike et al. (2014) debt to assets ratio (DAR) is calculated using the following formula:

DAR $=($ Total debt $) /($ Total assets $) \times 100 \%$

Debt to equity ratio (DER) is the ratio of total liabilities to total equity. Debt to equity ratio (DER) is used to measure how much equity (equity) as collateral for total liabilities, calculated as follows:

DER $=($ Total debt $) /($ Total equity $) \times 100 \%$

Long term debt to equity (LTDTE) is a comparison of total long-term liabilities with equity (equity). Long term debt to equity (LTDTE) is used to measure how much equity (equity) is available to meet long-term obligations. Referring to Cekresi (2013), and Chukwunweike et al. (2014), LTDTE is calculated by the following formula: LTDTE $=($ Total debt $) /($ Total equity $) \times 100 \%$

The capital structure is predicted as a determinant of financial performance and value.

\subsubsection{Business Risk Endogenous Variables (Y2)}

Business risk is the uncertainty that creates irregularities in the cash flow of a corporate's investment and operations and also the risks contained in the financing used. Business risk will be calculated by measuring changes in annual earnings before interest and tax (EBIT). Business risk refers to the deviation from income before interest and taxes (EBIT).

Dispersion of EBIT flows in a corporate as measured by the coefficient of deviation (standard deviation) is from several influences that are causally related. The business risk indicator is calculated as follows: The standard deviation can be known in advance the average return on assets, in the following ways:

$$
\begin{aligned}
& \text { Average returns }=\frac{\sum_{t=1}^{n} \text { returns in year } t}{\text { Number of years }}=\frac{\sum_{t=1}^{n}\left(k_{t}\right)}{n} \\
& \text { Deviation Standard }=\sqrt{\frac{\sum_{t=1}^{n}(\text { return on year } t-\text { average return })^{2}}{\text { number of years }-1}} \\
& \qquad \sigma=\sqrt{\frac{\sum_{t=1}^{n}\left(k_{t}-\bar{k}\right)^{2}}{n-1}} \text { (Keown et al., 2000:208-209). }
\end{aligned}
$$

Business risk is measured by the deviation standard of EBIT, and deviation standard of earnings after tax (earning after tax: EAT, referring to the research of Cekresi (2013); Masoud (2014); Gathogo and Ragui (2014). Business risk is predicted as a determinant of financial performance and value corporate.

3.4.4 Endogenous Variables in Financial Performance (Y3)

Financial performance is a financial achievement that shows a corporate's ability to manage its assets and 
generate profits. Financial performance is measured by return on assets (ROA), return on equity (ROE), net profit margin (NPM), and gross profit margin (GPM).

Return on assets (ROA) is the ratio of net income to total assets in a given time. Return on assets (ROA) is used to measure the ability of companies to manage assets to generate profits for the corporate, so as to increase the corporate's financial ability to fund projects that have a "positive net present value". Referring to the study of Umar et al. (2012); Bokhari and Khan (2013) Return on assets (ROA) are calculated using the following formula: $\mathrm{ROA}=($ Earnig after tax $) /($ Total assets $) \times 100 \%$

Return on equity (ROE) is the ratio of net income after tax to total equity in a given time. Return on equity (ROE) is used to measure the corporate's ability to obtain net income after tax available to equity owners, so as to increase the wealth of shareholders, as a result investors can assess management efficiency. Refer to Barakat's research (2014). Return on equity (ROE) is calculated using the following formula:

$\mathrm{ROE}=($ Earnig after tax $) /($ Equity $) \times 100 \%$

Net profit margin (NPM) is the ratio of net profit to total net sales in a given time. Net profit margin (NPM) is used to measure the corporate's ability to obtain an average net profit per unit of sale, and to measure sales performance. Referring to the research of Barakat (2014), Bkhari and Khan (2013) NPM is calculated using the following formula:

$\mathrm{NPM}=($ Earnig after tax $) /($ Net sales $) \times 100 \%$

Gross profit margin (GPM) is the ratio of gross profit to total net sales in a given time. Gross profit margin (GPM) is used to measure the corporate's ability to obtain an average gross profit per unit of sale, as well as measure sales performance. Referring to Almajali (2012) research Gross profit margin (GPM) is calculated using the following formula:

GPM $=($ Gross profit $) /($ Net sales $) \times 100 \%$

Financial performance is predicted as a determinant of corporate value.

\subsubsection{Endogenous Variable Enterprise Value (Y4)}

Corporate value is the market value of shares and book value. Indicators of corporate value, among others: Closing Price (CP), Price to Book value (PBV), Tobin's q. Closing Price (CP) is the price of shares traded on the capital market at the time of closing trading activities, referring to the study (Yulianto et al., 2014).

Companies that will conduct an initial public offering can use book value as a benchmark for assessing stock prices. Price to Book value (PBV) is a comparison of the stock market price with the book value of shares, which shows the value of the corporate according to the capital market valuation at a certain time. Referring to the research of Ghalandari (2013) and Asiri and Hameed (2014). PBV is calculated using the following formula:

$\mathrm{PBV}=($ Market price of Stock) / (Book value of Stock).

If $\mathrm{PBV}$ is 1 then the market price is proportional to book value. If this ratio is less than 1 , the market price is less than the book value, because the market is underestimating the corporate's shares. PBV reflects the value of the corporate. In general, a corporate that is running well has a PBV above 1 showing a market value higher than the book value, because the market highly values the corporate's shares. The higher stock returns will increase corporate revenue thereby increasing the corporate's ability to distribute dividends.

Market prices reflect the price expectations of investors, if investor expectations of one type of stock are high, then the demand for these shares is also high so that prices in the market are also relatively high, market prices can also be lower than the book value, therefore try using the Tobin's approach q to measure the value of the corporate. Tobin's q is the market value of equity plus total corporate debt divided by total assets. Referring to the research of Adi et al. (2013). Tobin's q is calculated using the following formula:

Tobin's Q = (Market Value of Equity + Total Debt) / (Total Assets).

It is predicted that the value of the corporate is determined by the activities of the use of assets, capital structure, and financial performance.

\subsubsection{Types and Sources of Data}

The type of data used in this study is secondary data in the form of financial statement documents and corporate annual reports, fact book Indonesia Stock Exchange. The data source used is the Indonesia Stock Exchange through the site http://www.idx.co.id

\subsubsection{Data Collection Methods}

In accordance with the types and sources of data needed, the data collection method used is the documentation method. Documents that will be used in the research are financial reports that have been audited by public accountants and annual reports, profiles of the corporate's financial performance, and fact books of the Indonesia Stock Exchange.

\section{Research Findings}

\subsection{Description of Statistics}

Descriptive statistical analysis aims to describe the data that has been collected as it is without intending to draw general conclusions or generalizations. The data described in the form of a minimum value, maximum 
value, average of each indicator forming latent variables, as listed in table 1, follows:

Table 1. Research Variable Indicator Values

\begin{tabular}{|c|c|c|c|c|c|c|c|c|c|c|}
\hline \multirow[t]{2}{*}{ No } & \multirow[t]{2}{*}{ Variable Indicator } & \multicolumn{6}{|c|}{ Average Per Year } & \multicolumn{3}{|c|}{6 year average } \\
\hline & & 2010 & 2011 & 2012 & 2013 & 2014 & 2015 & Min & Max & Mean \\
\hline \multirow[t]{6}{*}{1} & \multicolumn{3}{|c|}{ Asset Use Activity Variable (X) } & & & & & & & \\
\hline & CATO (x) & 2,15 & 2,20 & 2,20 & 2,14 & 2,18 & 2,00 & 0,50 & 5,51 & 2,14 \\
\hline & ITO $(\mathrm{x})$ & 7,67 & 7,35 & 7,14 & 6,91 & 6,90 & 6,77 & 1 & 64 & 7,12 \\
\hline & RTO (x) & 8,71 & 8,76 & 8,61 & 8,17 & 8,65 & 7,30 & 1 & 79,92 & 8,37 \\
\hline & FATO (x) & 3,36 & 3,93 & 3,68 & 3,48 & 3,32 & 2,85 & 0,27 & 16,04 & 3,44 \\
\hline & TATO (x) & 1,20 & 1,63 & 1,62 & 1,23 & 1,17 & 1,02 & 0,22 & 3 & 1,17 \\
\hline \multirow[t]{4}{*}{2} & \multicolumn{3}{|c|}{ Capital Structure Variable $\left(\mathbf{Y}_{1}\right)$} & & & & & & & \\
\hline & $\operatorname{DAR}(\%)$ & 44,45 & 43,24 & 42,70 & 44,70 & 43,61 & 43,60 & 4,00 & 121 & 43,72 \\
\hline & $\operatorname{DER}(\%)$ & 116,11 & 97,77 & 95,00 & 107,39 & 115,60 & 102,64 & 4,00 & 108 & 105,75 \\
\hline & LTDTE $(\%)$ & 35,59 & 28,41 & 27,28 & 32,40 & 31,74 & 34,85 & 0,40 & 207,5 & 31,71 \\
\hline \multirow[t]{3}{*}{3} & \multicolumn{2}{|c|}{ Business Risk Variable $\left(\mathrm{Y}_{2}\right)$} & & & & & & & & \\
\hline & Dev.EBIT( $\%)$ & 8,59 & 7,30 & 6,68 & 6,74 & 8,62 & 14,30 & 0,054 & 229,9 & 8,70 \\
\hline & Dev.EAT(\%) & 19,65 & 14,36 & 11,36 & 17,46 & 15,96 & 32,14 & 0,002 & 594,1 & 18,49 \\
\hline \multirow[t]{5}{*}{4} & \multicolumn{3}{|c|}{ Financial Performance Variable $\left(\mathrm{Y}_{3}\right)$} & & & & & & & \\
\hline & ROA ( \%) & 9,86 & 10,15 & 10,08 & 10,10 & 6,86 & 6,21 & $-16,00$ & 74,84 & 8,88 \\
\hline & $\operatorname{ROE}(\%)$ & 18,56 & 18,26 & 18,39 & 15,12 & 13,34 & 8,87 & $-48,00$ & 143,53 & 15,43 \\
\hline & NPM ( \%) & 8,48 & 8,38 & 8,43 & 7,77 & 6,12 & 4,59 & $-24,00$ & 50,87 & 7,29 \\
\hline & GPM ( \%) & 24,65 & 24,42 & 24,11 & 24,36 & 23,01 & 22,44 & $-16,29$ & 70,23 & 23,83 \\
\hline \multirow[t]{4}{*}{5} & \multicolumn{3}{|c|}{ Corporate Value Variable $\left(\mathbf{Y}_{4}\right)$} & & & & & & & \\
\hline & $\mathrm{CP}(\mathrm{Rp})$ & $10.940,05$ & $12.736,35$ & $18.787,64$ & $11.211,45$ & $11.366,14$ & $8.618,22$ & 50,00 & 740.000 & $12.726,6$ \\
\hline & $\mathrm{PBV}(\mathrm{x})$ & 2,49 & 2,58 & 3,30 & 3,01 & 3,34 & 2,72 & 0,04 & 58,48 & 2,90 \\
\hline & $\mathrm{Q}(\mathrm{x})$ & 1,79 & 1,82 & 2,08 & 2,06 & 2,03 & 2,14 & 0,26 & 18,64 & 1,99 \\
\hline
\end{tabular}

Data sources: corporate financial report, fact book BEI in site http://www.idx.co.id processed in 2017.

\subsection{Statistical Analysis with GSCA}

Steps of Data Analysis

1) Designing structural models (influence between latent variables). Structural models that show the influence between latent variables based on the formulation of the problem or research hypothesis.

2) Designing a measurement model is to determine the indicator properties of each latent variable, whether reflexive or formative.

3) Constructing the path diagram in the research model.

4) Converting the path diagram into the equation system, including: (a) Explain the effect of latent variables with their indicators, also called measurement models, defining the characteristics of latent variables with their indicators. (b) Explain the influence between latent variables (structural models), which describe the effects of latent variables based on the theory of substantive research. Without losing its generality, it is assumed that latent variables and indicators or manifest variables are standardized, so that constants $=0$ and can be removed from the model.

5) Estimation of Parameters

\subsubsection{Fit Model}

Test shows that the FIT value of 0.549 implies that the dependent latent variable can be explained by the independent latent variable in the structural model by 54.9 percent or in other words the information contained in the data can be explained by 54.9 percent by the model, while the remaining 45.1 percent is explained by other variables not yet included in the research model and error.

Considering the variables in the model of more than one independent latent will affect the dependent latent variable, it is more appropriate if the interpretation of the accuracy of the model uses the corrected FIT (AFIT) value. AFIT value of 0.547 implies that the dependent latent variable can be explained by the independent latent variable in the model by 54.7 percent or in other words the information contained in the data can be explained by 54.7 percent by the model, while the remaining 45.3 percent is explained by other variables that have not been included in the research model and error.

\subsubsection{Outer Model Test Results}

Outer model (Measurement Model) which explains the relationship between latent variables and their manifest indicator (measurement model). Based on the framework and conceptual model in chapter 2, an outer model which is often called an outer relation is developed, which defines how each block of indicators relates to the latent variable, the test results are obtained by calculating GSCA Bootstrapping. Outer weight and outer weight values indicate the weight of the value of each indicator as a measure of each latent variable. Indicators with the largest outer weight and outer weight indicate that the indicator is a measure of the strongest or dominant variable. The outer weight and outer weight indicators of the seven measured latent variables are obtained through GSCA Bootstrap calculations which also produce a critical ratio $(\mathrm{CR})$ value similar to the statistical $\mathrm{t}$ 
value, if the weight value is above 0.4 and the $\mathrm{CR}$ value is greater than $1,96 \mathrm{~T}$ table, then it was decided significant. The detailed test results are as in table 2, as follows:

Table 2. Measurement Model Test Results (Outer Model)

\begin{tabular}{|c|c|c|c|c|}
\hline \multirow[t]{2}{*}{ Indicator } & \multicolumn{3}{|c|}{ Weight } & \multirow[t]{2}{*}{ Information } \\
\hline & Estimate & SE & $\mathrm{CR}$ & \\
\hline \multicolumn{4}{|c|}{ Measurement Model of Asset Use Activity Variables (X) } & \\
\hline Carrent assets turnover (CATO) & 0.754 & 0.026 & $29.00 *$ & Significant \\
\hline Inventory turnover (ITO) & 0.407 & 0.063 & $6.46^{*}$ & Significant \\
\hline Receivable turnover (RTO) & 0.536 & 0.056 & $9.57 *$ & Significant \\
\hline Fixed asset turnover (FATO) & 0.686 & 0.030 & $22.87 *$ & Significant \\
\hline Total asset turnover (TATO) & 0.875 & 0.010 & $87.50 *$ & Significant \\
\hline \multicolumn{4}{|c|}{ Measurement Model of Capital Structure Variable (Y1) } & \\
\hline Debt to assets ratio (DAR) & 0.917 & 0.011 & $83.36^{*}$ & Significant \\
\hline Debt to equity ratio (DER) & 0.889 & 0.032 & $27.78^{*}$ & Significant \\
\hline Long term debt to equity (LTDTE) & 0.810 & 0.020 & $40.50 *$ & Significant \\
\hline \multicolumn{4}{|c|}{ Measurement Model of Business Risk (Y2) } & \\
\hline Deviation Standard EBIT (Dev. EBIT) & 0.858 & 0.022 & $39.00 *$ & Significant \\
\hline Deviation Standard EAT (Dev.EAT) & 0.825 & 0.027 & $30.56^{*}$ & Significant \\
\hline \multicolumn{4}{|c|}{ Measurement Model of Financial Performance Variable (Y3) } & \\
\hline Return on asset (ROA) & 0.950 & 0.013 & $73.08 *$ & Significant \\
\hline Return on equity (ROE) & 0.905 & 0.010 & $90.50 *$ & Significant \\
\hline Net profit margin (NPM) & 0.858 & 0.015 & $57.20^{*}$ & Significant \\
\hline Gross profit margin (GPM) & 0.729 & 0.032 & $27.78^{*}$ & Significant \\
\hline \multicolumn{4}{|c|}{ Measurement Model of Corporate Value Variable (Y4) } & \\
\hline Closing price $(\mathrm{CP})$ & 0.626 & 0.072 & $8.70 *$ & Significant \\
\hline Price to book value (PBV) & 0.943 & 0.011 & $85.73 *$ & Significant \\
\hline Tobin's q (Q) & 0.955 & 0.009 & $106.11 *$ & Significant \\
\hline \multicolumn{5}{|c|}{$\mathrm{CR}^{*}=$ Sgnificant at 0.05 level } \\
\hline \multicolumn{5}{|c|}{ Source: GSCA analysis results are processed in 2017.} \\
\hline
\end{tabular}

\subsubsection{Inner Model Test Results}

The inner model test results (structural model) explain the relationship between latent variables that describe the relationship between the independent latent variable and the dependent latent variable based on the substantive theory that defines the relationship of each independent latent variable with the dependent latent variable. The value of the path coefficient of influence between the independent latent variables on the dependent latent variable is obtained through the Generalized Structured Compoment Analysis (GSCA) calculation and a significant test is obtained through Bootstrapping which also finds the critical ratio (CR) value equivalent to $T$. The inner model test (structural model) in essence, testing the hypothesis in research. Hypothesis testing is done by the $\mathrm{T}$ test on each connecting path that affects the latent variables. Based on the results of the GSCA analysis, a hypothetical tested model is obtained, as in table 3, as follows:

Table 3. Structural Model test results (Inner Model)

\begin{tabular}{|l|l|l|l|l|l|l|}
\hline \multirow{2}{*}{ Hypothesis } & \multirow{2}{*}{ Path } & \multicolumn{5}{|c|}{ Path Coeficients } \\
\cline { 3 - 6 } & & Estimate & SE & CR (T) & \multicolumn{2}{c|}{ Information } \\
\hline H1 & $\mathrm{X} \rightarrow \mathrm{Y} 1$ & -0.082 & 0.040 & $2.05^{*}$ & Significant & H1 Accepted \\
\hline H2 & $\mathrm{X} \rightarrow \mathrm{Y} 2$ & -0.162 & 0.032 & $5.06^{*}$ & Significant & H2 Accepted \\
\hline H3 & $\mathrm{X} \rightarrow \mathrm{Y} 3$ & 0.380 & 0.041 & $9.27^{*}$ & Significant & H3 Accepted \\
\hline H5 & $\mathrm{X} \rightarrow \mathrm{Y} 4$ & 0.134 & 0.043 & $3.12^{*}$ & Significant & H4 Accepted \\
\hline H6 & Y1 $\rightarrow$ Y2 & 0.184 & 0.068 & $2.71^{*}$ & Significant & H5 Accepted \\
\hline H7 & Y1 $\rightarrow$ Y3 & -0.194 & 0.032 & $6.06^{*}$ & Significant & H6 Accepted \\
\hline H8 & Y1 $\rightarrow$ Y4 & 0.167 & 0.021 & $7.95^{*}$ & Significant & H7 Accepted \\
\hline H9 & Y2 $\rightarrow$ Y3 & -0.224 & 0.034 & $6.59^{*}$ & Significant & H8 Accepted \\
\hline H10 & Y2 $\rightarrow$ Y4 & -0.102 & 0.017 & $6.00^{*}$ & Significant & H9 Accepted \\
\hline CR* = Significant at 0,05 level & Y3 $\rightarrow$ Y4 & 0.783 & 0.037 & $21.16^{*}$ & Significant & H10 Accepted \\
\hline
\end{tabular}

Source: GSCA analysis results are processed in 2017.

\section{Discussion of Research Findings}

Discussion of the research findings is carried out on four variables namely: (1) Variables of asset use activities; 
(2) Variable capital structure; (3) Business risk variables; (4) Financial performance variables; (5) Corporate value variable.

\section{1 Variable Description}

\section{1.1 Asset Use Activity Variable (X)}

Asset use activity is a function of using funds to spend or invest in corporate assets to produce goods and services for sale. In operational activities the corporate will use assets that have been allocated for use. The better the use of assets by companies, will make sales higher and get higher profits as well (Gopal, 2009: 207). Financial managers are required to have to make decisions related to asset use activities, and ensure the smooth operation of the corporate. The financial manager will perform the funding function. The function of the use of funds includes planning and controlling the use of assets, both in current assets and fixed assets, and the allocation of funds that are embedded in each element of the asset is not too small or too large in amount. Because if it is too small, it can disrupt business liquidity and continuity, and on the other hand, if the amount is too large, it can cause ineffective use of assets.

The funding function in its implementation by the financial manager must make a decision on the selection of alternative funding or funding decisions. So the funding function can be interpreted as the overall activity of the corporate concerned to obtain the necessary funds with minimal costs and the most favorable conditions and try to use these funds as efficiently as possible. The function of the use of funds must be carried out efficiently and effectively, meaning that every fund embedded in the assets must be used as efficiently as possible to generate maximum profits, through increasing sales volume. The activity of using assets will determine the benefits achieved (Kamaludin and Indriani, 2012: 44). Companies must operate at a high level of activity, so that no assets are unemployed and the efficient use of assets will reduce the costs of managerial policies and increase profitability. Asset use activity can be measured by current assets turnover, inventory turnover, accounts receivable turnover, fixed asset turnover, and total asset turnover (Hanafi, 2010: 38-40).

Turnover rates reflect the relative productivity of each asset, or the level of sales volume obtained from each rupiah invested in a particular asset. High asset turnover rate is preferred over low assets (Subramanyam and Wild, 2013: 159-160). The higher asset turnover means the faster the return of funds into the corporate, so that sufficient internal funds are available for re-investment, and can reduce debt costs, and increase profits which are expected to increase wealth for the owners. Asset use activity variable (X) is measured by current asset turnover (CATO) indicators, inventory turnover (ITO), receivable turnover (RTO) indicators; Fixed asset turnover (FATO), total asset turnover (TATO).

The development of current turnover of manufacturing industry companies on the Indonesia Stock Exchange during 2010-2015 (table 1), namely: with the largest value occurring in 2011 and 2012 of 2.2 times and the smallest 2 times in 2015. Current assets turnover was the average is 2.14 times or the age of inventory is 365 days: 2.14 days $=170.56$ days. In general, manufacturing industry companies on the Indonesia Stock Exchange have a current asset turnover rate of 2.14 times or the age of current assets 365 days: 2.14 times $=$ 170.56 days. The results of the GSCA analysis (table 2) show that current assets turnover has a weight estimate of 0.754 or current assets turnover contributes 75.4 percent to asset use activities. This indicates that current assets turnover is a very strong indicator in measuring the activity of using assets. Current assets turnover has a very important role in ensuring the effectiveness and efficiency of the use of assets to increase corporate sales and accelerate cash withdrawals, so that working capital is always available in sufficient quantities.

Current assets turnover is used to measure the intensity of current assets utilization by the corporate (Subramanyam and Wild, 2013: 159-160). High current assets turnover indicates that the use of current assets is very effective in generating sales. Conversely the low level of current assets turnover indicates that the use of current assets that are less effective in generating sales. The development of inventory turnover of manufacturing industry companies in the Indonesia Stock Exchange during 2010-2015 (table 1), namely: with the largest value occurring in 2010 amounted to 7.67 times and the smallest 6.77 times in 2015. In general manufacturing industry companies on the Exchange Indonesian Securities has an average inventory turnover of 7.12 times or inventory age of 365 days: 7.12 days $=51.26$ days or an average ability to sell merchandise inventory within a year. The results of the GSCA analysis (table 2) show that inventory turnover has a weight estimate of 0.407 or inventory turnover contributes 40.7 percent to asset use activities.

A high inventory turnover indicates that the corporate's products are more competitive and that there is enough inventory to serve high market demand. Conversely, a low inventory turnover indicates that the corporate's products are less competitive and market demand is low, while the amount of inventory is too large. The corporate wants an inventory of goods in sufficient quantities to meet customer needs without excess or running out of inventory (Subramanyam and Wild, 2013: 160-161).

The development of receivable turnover of manufacturing industry companies in the Indonesia Stock Exchange during 2010-2015 (table 1), namely: with the largest value occurring in 2011 amounting to 8.76 times and the smallest 7.3 times in 2015. Manufacturing industry companies on the Indonesia Stock Exchange has an 
average level of accounts receivable turnover of 8.37 times a year or the age of receivables is 365 days: 8.37 times $=43.61$ days. This means that in general, manufacturing industry companies on the Indonesia Stock Exchange have the ability to collect receivables within 43.61 days. The results of the GSCA analysis (table 2) show that accounts receivable turnover has a weight estimate of 0.536 or accounts receivable turnover contributes 53.6 percent of asset use activities. High accounts receivable turnover rates indicate that companies sell merchandise on credit less than sell in cash, serve customers who have enough cash to pay in cash and increase sales volumes. On the other hand, a low level of accounts receivable turnover indicates that companies sell more merchandise on credit to serve customers who do not have enough cash to pay in cash. It can thus increase sales volume and anticipate inventory buildup.

The development of fixed asset turnover of manufacturing industry companies in the Indonesia Stock Exchange during 2010-2015 (table 1), namely: with the largest value occurring in 2011 amounted to 3.93 times and the smallest 2.85 times in 2015. Manufacturing industry companies on the Stock Exchange Indonesia has an average turnover of fixed assets is 3.44 times a year or the time for one time turnover of fixed assets is 365 days: 3.44 times $=106.10$ days. This means that in general the corporate has the ability to use fixed assets to generate sales in one round takes 106.10 days. The results of the GSCA analysis (table 2) show that fixed asset turnover has a weight estimate of 0.686 or fixed asset turnover contributes 68.6 percent to asset use activities. Turnover of fixed assets is used to measure the intensity of the utilization of fixed assets by companies (Subramanyam and Wild, 2013: 161). The high level of fixed asset turnover indicates that the use of fixed assets is very effective in generating sales. On the other hand, a low level of fixed asset turnover indicates that the use of fixed assets is less effective in generating sales. Turnover of fixed assets can be increased through increased production and product sales, without increasing the number of existing fixed assets.

The development of total asset turnover of manufacturing industry companies in the Indonesia Stock Exchange during 2010-2015 (table 1), namely: with the largest value occurring in 2011 amounted to 1.63 times and and 2012 amounted to 1.62 times and the smallest 1.02 times in the year 2015. Manufacturing industry companies on the Indonesia Stock Exchange have an average total asset turnover rate of 1.17 times a year or the time for a total asset turnover is 365 days: 1.17 times $=311.97$ days. This means that in general, manufacturing industry companies in the Indonesia Stock Exchange have the ability to use all assets to generate sales in one round, which requires 311.97 days. The results of the GSCA analysis (table 2) show that total asset turnover has a weight estimate of 0.875 or total asset turnover contributes 87.5 percent to asset use activities

Noting that the total assets turnover is still low, it means that the corporate has not been effective in using all existing assets. In principle, the corporate wants a high total asset turnover. A high total asset turnover indicates that the use of total assets is very effective in generating sales. Asset turnover can be increased through increased production and product sales, without increasing the number of existing assets.

Activity ratio describes how much efficiency the use of assets by companies, as well as how much funds are embedded in each group of assets of manufacturing industry companies on the Indonesia Stock Exchange. If the funds that are embedded in certain assets are large enough, while those funds should be able to be used for investments in other assets that are more productive, then profitability is not as good as it should be. The use of assets that are efficient and effective has an impact on reducing debt because there are savings, so as to increase profits (financial performance) and corporate value. Asset use activities will affect capital structure, financial performance and corporate value.

\subsubsection{Capital Structure Variable (Y1)}

Capital structure is a combination of debt and equity in financing the operations of a corporate called leverage. Chou and Lee (2010) argue that the capital structure is a mixture of debt and equity fund sources including reserves and profits from the corporate. Leverage refers to the proportion of debt to equity in a corporate's capital structure. Capital structure variable (Y1) is measured by indicators of total debt to total assets ratio (DAR), debt to equity ratio (DER) and long term debt to equity (LTDTE) (Boakye et al., 2013; Sangeetha, 2013; Saeed et al. ., 2014; Masoud, 2014; Tronyeva, 2013; Gathogo and Ragui, 2014).

Total debt to total assets ratio (DAR) is the ratio of total liabilities to total assets that shows the relationship between total liabilities and total assets. The total debt to total assets ratio is used to measure how much the corporate's assets are financed by debt. If the corporate has a high debt, it will burden the corporate to pay the fixed interest and principal loan obligations. Finally, the corporate must deal with the risk of bankruptcy if it fails to pay debts. Companies often use less debt than their own capital to obtain capital structures that produce high profits.

The development of total debt to total asset ratio of manufacturing industry companies on the Indonesia Stock Exchange during 2010-2015 (table 1), namely: with the largest value occurring in 2013 amounting to 44.70 percent and the smallest 42.70 percent in 2012 . The average value - the average DAR indicator is 43.72 percent, which means that in general the sample companies are funded with a debt of 43.72 percent.

The GSCA analysis (table 2) shows that the total debt to total asset ratio has a weight estimate of 0.917 or the total debt to total asset ratio contributes 91.7 percent to the capital structure. This indicates that the debt to 
assets ratio (DAR) is a very strong indicator in measuring capital structure. Debt has a very important role in the corporate's capital structure to guarantee the funds needed to finance the corporate's assets.

Debt to equity ratio (DER) is the ratio of total liabilities to total equity which shows the relationship between total liabilities and total equity. Debt to equity ratio (DER) is used to measure how much own capital as collateral for total liabilities. The development of the total debt to equity ratio of manufacturing industry companies in the Indonesia Stock Exchange during 2010-2015 (table 1), namely: with the largest value occurring in 2010 amounting to 116.11 percent and the smallest 95 percent in 2012. The average value of the DER indicator amounted to 103.82 percent, meaning that in general the companies that were sampled had a debt value of 103.82 percent or Rp. 1.0382 debt while the value of its own capital was Rp. 1 used in funding corporate assets. The results of the GSCA analysis (table 2) show that the total debt to equity ratio has a weight estimate of 0,889 or the total debt to equity ratio contributes 88.9 percent to the capital structure. Manufacturing industry companies on the Indonesia Stock Exchange are financed by bigger debt than equity.

Long term debt to equity (LTDTE) is a comparison of total long-term liabilities with equity (equity) which shows the relationship between long-term debt and equity. Long term debt to equity (LTDTE) is used to measure how much equity (equity) is available to meet long-term obligations. Where equity does not burden companies to pay fixed interest costs. In this calculation using long-term debt that has a fixed interest to be paid by the corporate, the consideration is in relation to the risk of the corporate due to increased debt costs. The development of long-term debt to equity of manufacturing industry companies in the Indonesia Stock Exchange during 2010-2015 (table 1), namely: with the largest value occurring in 2010 amounted to 35.59 percent and the smallest 27.28 percent in 2012. The average value LTDTE indicator is 31.71 percent; means that manufacturing industry companies on the Indonesia Stock Exchange in general have a long-term debt of 31.71 percent or Rp. 0.3171 long-term debt while own capital of Rp. 1 .

The results of the GSCA analysis (table 2) show that long term debt to equity has a weight estimate of 0 , 810 or long term debt to equity contributes 81 percent to the capital structure. This shows that the sample companies are financed by long-term debt smaller than their own capital. In terms of solvency, it means that industrial companies listed on the Indonesia Stock Exchange have good solvency.

The three indicators of capital structure variables (Y1), namely: DAR, debt to equity ratio (DER), and LTDTE are significant means to have the ability to measure capital structure variables. The results of an analysis of DAR, DER, LTDTE indicate the ratio of debt owned by manufacturing industry companies on the Indonesia Stock Exchange. The capital structure is influenced by the activity of asset use, as well as other variables not examined in this study. Capital structure further influences financial performance and corporate value. The main purpose of capital structure decisions is to maximize the value of the corporate through the right combination of debt and equity in financing a corporate's operations. Determining the right capital structure will minimize the cost of capital. In 1958 Modigliani and Miller proposed the theory of the corporate's capital structure. Modigliani and Miller's theory first concluded that without taxes, the corporate owes or does not owe no effect on the value of the corporate. In 1963 Modigliani and Miller continued the theory of capital structure. Assuming there is income tax, the corporate can use high debt to save taxes so that it will increase the value of the corporate because the cost of debt interest will reduce tax payments. However, excessive use of debt will increase the cost of capital which decreases the value of the corporate.

\section{1.3 Business Risk Variable (X3)}

Keown et al. (1999: 494-496) say that business risk is the uncertainty or deviation of income before interest and taxes, and also the risks contained in the financing used. Deviations are called return on assets variability and are influenced by investment decisions. Financial risk is a variable increase in returns for ordinary shareholders as a result of financing with debt or preferred shares. When financial risk increases, the rate of return required by investors and the cost of capital will move in the same direction. The final factor that determines the cost of funds is the level of financing required by the corporate. As finance increases, the weighted cost of capital increases, for several reasons. For example, the more securities issued, the additional costs obtained by the corporate from the securities issued will affect the cost of the corporate's funds. Also if management enters the market for the amount of capital relative to the size of the corporate, the rate of return required by the investor will increase.

Capital providers will be hesitant to give large amounts of funds without proof of management's ability to absorb funds into the business. This is often called "too much too fast". Increasing the number of issuance of securities will make it difficult at the time of bidding in the market, thus forcing companies to lower the price of these securities, will also increase the cost of capital companies. Financial risks associated with the threat of bankruptcy. If the percentage of debt in the capital structure increases, the interest expense also increases and the corporate may not be able to pay interest and principal. Keown et al. (1999: 494-496) say that business risk is a deviation from income before interest and taxes. The dispersion of earnings before interest and tax (EBIT) flows measured by the coefficient of deviation is the result of several effects that are related to cause and effect. Like the cost structure of a corporate, the characteristics of product demand, competitive position in the industry 
affect the business risk of the corporate.

The risk itself is a result of investment decisions from the corporate. The business risk variable (Y2) is measured by the deviation standard indicator of net income before interest and tax (earnings before interest and tax: EBIT) and the deviation standard of EAT (Dev. EAT). The development of the deviation standard of net profit before tax (Dev. EBIT) of manufacturing industry companies in the Indonesia Stock Exchange during 2010-2015 (table 1), namely: with the largest value occurring in 2015 of 14.30 percent and the smallest 6.68 percent in the year 2012. The average value of the deviation standard indicator for net income before tax is 8.70 percent, meaning that in general the manufacturing industry companies on the Indonesia Stock Exchange have a business risk level of 8.70 percent as measured by the standard deviation of net income before interest and taxes (earnings before interest and tax: EBIT). The results of the GSCA analysis (table 2) show that the deviation standard of net income before tax has a weight estimate of 0.858 or the deviation standard of net income before tax contributes 85.8 percent to business risk.

Development of net profit after tax deviation standard (EAT deviation standard) of manufacturing industry companies in the Indonesia Stock Exchange during 2010-2015 (table 1), namely: with the largest value occurring in 2015 at 32.14 percent, and the smallest at 11.36 percent at in 2012 . The average value of the standard deviation indicator for net profit after tax was 18.49 percent, meaning that in general manufacturing industry companies on the Indonesia Stock Exchange had a business risk level of 18.49 percent as measured by the deviation standard of net profit after tax ( earning after tax: EAT). The results of the GSCA analysis (table 2) show that the standard deviation of net profit after tax has a weight estimate of 0.825 or the standard deviation of net income before tax contributes 82.5 percent to business risk.

The two indicators of business risk variables (X3), namely EBIT deviation standard and deviation standard are statistically significant. This means that the deviation of net income before interest and tax (earning before interest and tax: EBIT) and the deviation of net profit after tax (earning after tax: EAT) are very strong indicators in measuring the business risk of manufacturing industry companies on the Indonesia Stock Exchange. Earnings deviations indicate that the corporate faces an uncertainty in business that will affect capital structure, financial performance and corporate value.

\subsection{Financial Performance Variable (Y3)}

Financial performance is the results achieved by the corporate by using or managing resources efficiently and effectively in order to achieve the goals set in a certain time. Where the measurement of financial performance can be seen in the financial ratios of the corporate itself (Keown et al., 1999: 77-78). Financial performance is measured by return on assets (ROA), return on equity (ROE), net profit margin (NPM), and gross profit margin (GPM). Return on assets (ROA) is the ratio of net income to total assets within a certain time period that shows the relationship between net income and total assets. Return on assets (ROA) is used to measure the ability of companies to manage assets to generate profits, so as to increase the corporate's financial ability to fund projects that have a "positive net present value" (Brakat, 2014).

The development of return on assets of manufacturing industry companies in the Indonesia Stock Exchange during 2010-2015 (table 1) namely: with the largest value occurring in 2011 at 10.15 percent and the smallest 6.21 percent in 2015. The average value of the ROA indicator is 8.88 percent or $0.0888: 1$ meaning that every Rp. 1 of assets produces a net profit of Rp. 0.0888. This means that in general the manufacturing industry companies on the Indonesia Stock Exchange have a net profit of Rp.0,0888 of each asset rupiah. The results of the GSCA analysis (table 2) show that return on assets has a weight estimate of 0.950 or return on assets contributes 95 percent of financial performance. This indicates that return on assets (ROA) is a very strong indicator in measuring financial performance. Return on assets has a very important role to measure the corporate's ability to generate profits which is the return of corporate assets from the investments made.

Return on equity (ROE) is a comparison of net income after tax with total equity over a period of time that shows the relationship between. net profit after tax with total equity. Return on equity (ROE) is used to measure the corporate's ability to obtain net income after tax available to equity owners, so as to increase the wealth of shareholders, and consequently investors can assess management efficiency. Investors will increasingly trust and provide opportunities for management to manage the corporate. The development of return on equity of manufacturing industry companies in the Indonesia Stock Exchange during 2010-2015 (table 1), namely: with the largest value occurring in 2010 at 18.56 percent and the smallest 8.87 percent in 2015 . The average value of the ROE indicator is 15.43 percent or 0.1543 meaning that every Rp. 1 of its own capital generates a profit of Rp. This means that in general the manufacturing industry companies on the Indonesia Stock Exchange have a net profit of Rp.0,1543 from every rupiah of their own capital. The results of the GSCA analysis (table 2) show that return on equity has a weight estimate of 0,905 or return on equity contributing 90.5 percent to financial performance.

Net profit margin (NPM) is the ratio of net income to total net sales results within a certain time period which shows the relationship between net income and total net sales results per unit average. Net profit margin (NPM) is used to measure the ability of companies to obtain an average net profit per unit of sale, and to 
measure sales performance (Almajali, 2012; Omondi and Muturi, 2013; Alzorqan, 2014; Adi et al., 2013; Chukwunweike et al., 2014). The development of net profit margins of manufacturing industry companies on the Indonesia Stock Exchange during 2010-2015 (table 1), namely: with the largest value occurring in 2010 of 8.48 percent and the smallest 4.59 percent in 2015. The average value of the NPM indicator is 7.29 percent or 0.0729: 1 meaning that every Rp.1 of sales generates a net profit of Rp.0,0729. This means that in general the manufacturing industry companies on the Indonesia Stock Exchange have a net profit of Rp. 0.0729 from every net sales rupiah. The results of the GSCA analysis (table 2) show that net profit margin has a weight estimate of 0,858 or net profit margin contributing 85.8 percent to financial performance.

Gross profit margin (GPM) is the ratio of gross profit to total net sales results within a certain time period which shows the relationship between gross profit and total net sales results. Gross profit margin (GPM) is used to measure the corporate's ability to obtain an average gross profit per unit of net sales, as well as measure sales performance. The development of gross profit margins of manufacturing industry companies on the Indonesia Stock Exchange during 2010-2015 (table 1), namely: with the largest value occurring in 2010 amounted to 24.65 percent and the smallest 22.44 percent in 2015. The average value of the GPM indicator is 23.83 percent percent or 0.2383 : 1 meaning that every Rp. 1 of sales generates a gross profit of Rp.0,2383. This means that in general the manufacturing industry companies on the Indonesia Stock Exchange have a gross profit of Rp.0,2383 from every net sales rupiah. The GSCA analysis (table 2) shows that the gross profit margin has a weight estimate of 0.729 or the gross profit margin contributes 72.9 percent to financial performance.

The corporate's goal is to maximize the welfare of its owners through the profitability achieved. The corporate's profitability will largely determine the viability of the corporate, and the corporate will grow depending on additional cash flow from profits obtained as a source of internal funding. The ability of the corporate to generate profits will determine the ability to provide funds to finance the corporate's growth and dividends or capital gains so as to increase the owner's wealth. If the corporate has good (high) financial performance, it will be a positive signal from the corporate to the market, so that many investors are interested in buying shares and making stock prices go up. The more people who will buy, the price will go up and the opposite will happen if the corporate is under-performing. The four indicators of financial performance variables (Y2), namely: ROA, ROE, NPM, and GPM are statistically significant, meaning that they have the ability to measure financial performance variables. The results of the analysis of ROA, ROE, NPM, and GPM indicate that financial performance is owned by manufacturing industry companies on the Indonesia Stock Exchange. Financial performance is influenced by corporate growth, liquidity, business risk, asset use activities, capital structure and other variables not examined in this study. Financial performance further affects the value of the corporate.

\section{1.5 Corporate Value Variable (Y4)}

The value of the corporate is the same as the share price, that is the number of shares multiplied by the market value per share, so any increase in share price will increase the value of the corporate, or a decrease in share price will decrease the value of the corporate (Kamaludin and Indriani, 2012: 4). Modigliani and Miller (1958) argue that the value of the corporate is the value of the corporate depends only on the flow of income generated by assets. The value of the corporate's equity is the total value of shares plus net income. Net income is derived from net operating income less the cost of debt interest and taxes. Indicators of corporate value are Closing price (CP), Price to book value (PBV), Tobin's q.

Closing price $(\mathrm{CP})$ is the price of shares traded on the capital market at the time of closing trading activities. The development of the closing price (CP) of manufacturing industry companies in the Indonesia Stock Exchange during 2010-2015 (table 1), namely: with the largest value occurring in 2012 amounting to Rp.18,787.64 and the smallest of Rp.8,618.22 in 2015. Average value CP indicator average is Rp. 12,726,6. The GSCA analysis (table 2) shows that the closing price has a weight estimate of 0.626 or the closing price contributes 62.6 percent to the corporate's value.

Companies that will conduct an initial public offering can use book value as a benchmark for assessing stock prices. Price to book value (PBV) is a comparison of the stock market price with the book value of shares, which shows the value of the corporate according to the capital market valuation at a certain time, which shows the relationship between book value and stock market price (Ghalandari, 2013). If PBV is 1 then the market price is proportional to book value. If the PBV ratio is less than 1, the market price is less than the book value, meaning the market values the corporate's shares lower. PBV can also reflect the corporate's value. Companies that run well generally have PBV above 1, which shows a market value higher than the book value. Increased PBV, will also increase stock returns. An increase in stock returns will increase corporate revenue thereby increasing the corporate's ability to distribute dividends. The development of price to book value (PBV) of manufacturing industry companies in the Indonesia Stock Exchange during 2010-2015 (table 1), namely: with the largest value occurring in 2014 of 3.34 times and the smallest of 2.72 times in 2015 . Value the average PBV indicator is 2.90 times the book value of equity, meaning that manufacturing industry companies on the Indonesia Stock Exchange have a market value of equity higher than the book value of equity. The results of the 
GSCA analysis (table 2) show that the price to book value has a weight estimate of 0.943 or the price to book value contributes 94.3 percent to the corporate's value.

In reality there are so many variations about PBV that market prices reflect the expectations of investors. If investor expectations of the price of one type of stock will rise, the demand for these shares will also be high so prices in the market are also relatively high. Market prices can also be lower than the book value, so try using Tobin's q approach to measure the value of the corporate. Tobin's q is the market value of equity plus total debt divided by total assets at any given time which shows the relationship between the market value of equity plus total debt with total assets (Adi et al., 2013). Tobin's q development of manufacturing industry companies in the Indonesia Stock Exchange during 2010-2015 (table 15), namely: with the largest value occurred in 2015 amounted to 2.14 times and the smallest was 1.79 times in 2010 . The average value of the Tobin's q indicator is 1,932 times; meaning generally the book value of the assets of manufacturing industry companies on the Indonesia Stock Exchange is 1,932 above the market value.

The GSCA analysis (table 2) shows that the market value of equity plus total debt divided by total assets has a weight estimate of 0.955 or the market value of equity plus total debt divided by total assets (Tobin's q) contributes 95.5 percent of the corporate's value. This indicates that Tobin's q which is the market value of equity plus total corporate debt divided by total assets is a very strong indicator and has a very important role in measuring the value of the corporate. The three indicators of corporate value variables (Y3), namely: CP, PBV, and Tobin's q are statistically significant, meaning that they have an impact to measure the corporate value variable. The results of the analysis of CP, PBV, and Tobin's q (Q) indicate that the value companies are owned by manufacturing industry companies on the Indonesia Stock Exchange. Corporate value is influenced by corporate growth, liquidity, business risk, asset use activities, capital structure and financial performance, as well as other variables not examined in this study.

\section{2 Effect Between Variables}

\subsubsection{The Effect of Asset Use Activities on Capital Structure}

Asset use activity $(\mathrm{X})$ has a significant effect on capital structure (Y1), the path coefficient value is -0.082 ; CR value of $2.05^{*}$ greater than 1.96; at the level $\mathrm{P}=0.05$ (table 3 ). The test results show enough empirical evidence to accept the hypothesis that "the activity of using assets has a significant effect on the corporate's capital structure", so hypothesis 1 is accepted. The results of statistical evidence show a negative and significant path coefficient. The path coefficient is negative, meaning an increase in asset use activity will reduce capital structure. The path coefficient of the effect of the use of assets on the capital structure of -0.082 can be interpreted that every increase in the use of assets of 1 rupiah will result in a decrease in debt in the composition of the capital structure of $-0,082$ rupiah. The theoretical implication of this empirical study is that increasing the activity of using assets decreases the capital structure. This can happen because an increase in net sales findings shows that the corporate is operating effectively, so that it can accelerate cash receipts. Fast cash returns make available funds available for reinvestment and reduce debt and interest costs.

\subsubsection{The Effect of Asset Use Activities on Business Risk}

Asset use activity (X) has a significant effect on business risk (Y2), the path coefficient value is -0.162 ; CR value of $5.06 *$ is greater than 1.96; at the level $\mathrm{P}=0.05$ (table 3). Test results show enough empirical evidence to accept the hypothesis that "Asset use activities have a significant effect on business risk", so hypothesis 2 is accepted. The results of statistical evidence show a negative and significant path coefficient. The negative path coefficient means that increasing the activity of using assets will reduce business risk. The path coefficient of the influence of the activities of using assets to business risk of -0.162 can be interpreted that any increase in asset use activity of 1 rupiah will result in a decrease in debt in the composition of capital structure of -0.162 rupiah. The theoretical implication of this empirical study is that increasing the activity of using assets will reduce business risk. This can happen because an increase in net sales results shows that the corporate is operating effectively, so that it can accelerate cash receipts.

Fast cash returns make available funds available for reinvestment and reduce debt and interest costs. Companies that have large cash flows will also have the opportunity to invest in new projects that are profitable, thereby reducing the risk of losing business opportunities. The theoretical implication of the effect of the activity of using assets to business risk is an increase in the ratio of assets use activities will reduce business risk.

\subsubsection{The Effects of Asset Use Activities on Financial Performance}

Asset Use Activity (X) significantly influence financial performance (Y3), path value of 0.380 CR value 9.27* greater than 1.96; at the level $\mathrm{P}=0.05$ (table 3). The test findings show enough empirical evidence to accept the hypothesis that "Asset use activities have a significant effect on financial performance", so hypothesis 3 is accepted.

The results of statistical evidence show a positive and significant path coefficient. A positive path coefficient means an increase in asset use activity will improve financial performance. The path coefficient of the influence of the activity of using assets on financial performance of 0.380 can be interpreted that every 
increase in asset use activity of 1 rupiah will result in an increase in financial performance of 0.380 rupiah. The theoretical implication of this empirical study is an increase in the activity of using financial performance assets. This can happen because an increase in net sales findings shows that the corporate is operating effectively, so that it can accelerate cash receipts. Fast cash returns make the amount of funds available to reinvest and make a profit.

The use of funds must be done efficiently and effectively in order to increase maximum profits. The function of the use of funds includes planning and controlling the use of assets, both in current assets and fixed assets, and the allocation of funds embedded in each element of the asset is not too small in number so that it can disrupt business liquidity and continuity, and other parties are not too large in number causing unemployment fund. A corporate that operates on high activity means that no assets are unemployed so that the efficient use of assets results in a decrease in managerial policy costs and increases corporate profitability.

Leverage irrelevance theory (Modigliani and Miller, 1958) argues that investment decisions determine profits and impact on corporate value. The logic of investment decisions is to decide what investment is chosen, how much the investment value is, when and where the investment is carried out. After the investment is made, it will then carry out activities of the production process using assets that have been allocated for their use by the corporate to find goods or services for sale and to find income. So investment decisions alone are not enough to have an impact on financial performance and value, but must also be supported by activities that use assets that are effective and efficient for generating income or profits.

Companies that operate effectively and efficiently will get high profits, so that they have retained earnings and reduce debt, as suggested by pecking order theory (Myers and Majluf, 1984). High asset usage activities reflect efficiency in asset management by companies (Kamaludin and Indriani, 2012: 44). Du-Pont analysis provides an analytical framework that connects activity ratios, debt ratios, and profitability ratios to determine return on equity (Hanafi, 2010: 51-52). Effective and efficient use of asset activities will reduce debt costs, can increase profits and corporate value.

\subsubsection{The Effect of Use of Asset Activities on Corporate Value}

Asset use activity $(\mathrm{X})$ has a significant effect on corporate value (Y4), the path coefficient value is 0.134 ; CR value $3.12 *$ greater than 1.96; at the level $\mathrm{P}=0.05$ (table 3 ). The test results show enough empirical evidence to accept the hypothesis that "Asset use activities have a significant effect on corporate value, so hypothesis 4 is accepted. The results of statistical evidence show a positive and significant path coefficient. Positive path coefficient, means that the increase in the use of assets will increase the value of the corporate. The path coefficient of the influence of the activities of using assets on the corporate value of 0.134 can be interpreted that every increase in asset use activity of 1 rupiah will cause an increase in the value of the corporate of 0.134 rupiah. The theoretical implication of this empirical study is that an increase in asset use activities will increase corporate value. This can happen because an increase in net sales shows that the corporate is operating effectively, so that it can accelerate cash receipts. Fast cash returns make the amount of funds available to reinvest and make a profit and add value to the corporate.

\subsubsection{The Effects of Capital Structure on Business Risk}

Capital structure (Y1) has a significant effect on business risk (Y2), the path coefficient value is 0.184; CR value of $2.71^{*}$ greater than 1.96; at the level $\mathrm{P}=0.05$ (table 3 ). The test results show enough empirical evidence to accept the hypothesis that "capital structure has a significant effect on business risk" so hypothesis 5 is accepted. The results of statistical evidence show a positive and significant path coefficient. A positive path coefficient means an increase in debt in the capital structure will increase business risk. The path coefficient of the influence of capital structure on business risk of 0.184 can be interpreted that each debt in the capital structure composition of 1 rupiah will result in a decrease in financial performance of 0.184 rupiah. The theoretical implication of this empirical study is that increasing the capital structure to a certain extent will increase business risk. This can happen, because debt in the capital structure has interest costs that will increase the risk of the corporate's business. If the debt is higher the interest costs will also rise and have an impact on decreasing profits and increasing the risk of failure if it fails to pay debts.

\subsubsection{The Effects of Capital Structure on Financial Performance}

Capital structure (Y1) has a significant effect on financial performance (Y2), the path coefficient value is -0.194 ; $\mathrm{CR}$ value of $6.06^{*}$ is greater than 1.96; at the level $\mathrm{P}=0.05$ (table 3 ). The test results show enough empirical evidence to accept the hypothesis that "capital structure has a significant effect on financial performance" so hypothesis 6 is accepted.

The results of statistical evidence show a negative and significant path coefficient. The negative path coefficient means that an increase in debt in the capital structure will reduce financial performance. The path coefficient of the influence of capital structure on financial performance of -0.194 can be interpreted that each debt in the composition of the capital structure of 1 rupiah will result in a decrease in financial performance of 0,194 rupiah. The theoretical implication of this empirical study is that increasing the capital structure to a certain extent will reduce financial performance. This can happen, because debt in the capital structure has 
interest costs that will reduce the corporate's profit. If debt gets higher the interest costs will also go up and have a negative impact on corporate profits.

The findings of this study support the pecking order theory (Myers and Majluf, 1984) predicting a negative correlation between profitability and capital structure. High debt will increase the fixed costs of debt along with additional debt, and transaction costs, debt agency costs, will force cash outflows that have a negative impact on financial performance and the probability of bankruptcy if the corporate experiences financial difficulties.

The findings of this study support the research findings of Umar et al. (2012), Ogebe (2013), Bokhari and Khan (2013), Omondi and Muturi (2013), Pontoh and Ilat (2013), Chukwunweike et al. (2014), Marobhe (2014) found that capital structure has a significant and negative effect on financial performance. Companies that have the ability to find high profits generally have a low level of debt, so that they will have lower risk.

Capital structure has an important role in determining the corporate's financial performance, as explained by the pecking order theory (Myers and Majluf, 1984) states that companies prefer internal funding sources rather than external funding sources. So companies that have large retained earnings will reduce the use of debt, because high debt will add fixed costs which have a negative impact on financial performance. The order of funding preferences is from one, which is the most sensitive to another, because asymmetric information between corporate management has more information and market participants (investors and prospective investors) who lack information about the condition of assets and investment opportunities as well as the corporate's prospects in the future (Myers and Majluf, 1984).

The findings of this study do not support trade off theory (Modigliani and Miller, 1963) predicting a positive correlation between capital structure with profitability or financial performance. Reduction of debt interest in the calculation of taxable income will reduce the proportion of the tax burden, so that net profit after tax becomes more available to shareholders. Net profit after tax available to shareholders can be measured by return on equity. The trade off of tax benefits on debt costs, so that companies benefit from the tax benefits of debt and have a positive impact on financial performance, means that increasing the debt ratio will improve financial performance. The theoretical and empirical explanations show that capital structure has positive and negative impacts on financial performance.

\subsubsection{The Effect of Capital Structure on Corporate Value}

Capital structure (Y1) has a significant effect on corporate value (Y4), path coefficient value of 0.167; CR value of $7.95^{*}$ greater than 1.96; at the level $\mathrm{P}=0.05$ (table 3 ). The test findings show enough empirical evidence to accept the hypothesis that "capital structure has a significant effect on corporate value", so hypothesis 7 is accepted.

The finding of statistical evidence shows a positive and significant path coefficient. A positive path coefficient means an increase in debt in the capital structure to a certain degree will increase the value of the corporate. The path coefficient of the influence of capital structure on financial performance of 0.167 can be interpreted that any increase in debt in the composition of capital structure of 1 rupiah will result in a decrease in financial performance of 0.167 rupiah. The theoretical implication of this empirical study is that increasing the capital structure to a certain extent will increase the value of the corporate.

Capital structure influences corporate value, as explained by trade off theory, pecking order theory, and leverage signaling theory that capital structure has a significant influence and direction of positive relationship to corporate value. The findings of this study support the trade off theory (Modigliani and Miller, 1963) predicting a positive relationship between capital structure and corporate value with the assumption that tax profits are still greater than the costs of financial difficulties and agency costs, then the tax benefits on the use of debt will have a positive impact on corporate value (Barakat, 2014).

The findings of this study support the pecking order theory (Myers and Majluf, 1984) that if companies want to use external funding sources, they must choose debt before new equity, because debt is cheaper and less sensitive to asymmetric information, so that the capital market will react positively towards debt issuance and makes the corporate's stock price go up. Conversely, if a corporate wants to issue new shares, the costs are higher and very sensitive to asymmetric information, so that the capital market will react negatively to the issuance of new shares, and make the corporate's stock prices go down (Ogbulu and Emeni, 2012).

The findings of this study support the leverage of signaling theory (Ross (1977) argues that debt becomes a credible signal about the quality and prospects of the corporate in the future, so that the market will react positively to the corporate's stock price. The findings of this study support the research findings of Chowdhuri and Chowdhuri (2010), Ogbulu and Emeni (2012), Oluwabemiga (2013), Barakat (2014), Isaac (2014) found that capital structure has a significant and positive effect on corporate value.

The findings of this study do not support the research findings of Ghalandari (2013), Adi et al. (2013), Asiri and Hameed (2014), Siahaan et al. (2014) found that capital structure has a significant and negative effect on corporate value. The theoretical implication of the empirical study is that increasing the capital structure to some extent will reduce the value of the corporate. The theoretical and empirical explanations show that capital structure has positive and negative impacts on corporate value. 


\subsubsection{The Effect of Business Risk on Financial Performance}

Business risk $\left(\mathrm{Y}_{2}\right)$ has a significant effect on financial performance $\left(\mathrm{Y}_{3}\right)$, the path coefficient value is -0.224 ; $\mathrm{CR}$ value of $6.59 *$ is greater than 1.96 ; at the level of $\mathrm{P}=0.05$. The test results show enough empirical evidence to accept the hypothesis that "Business risk has a significant effect on financial performance", so hypothesis 8 is accepted. The results of statistical evidence show a negative and significant path coefficient. The negative path coefficient means that increasing business risk will reduce financial performance. The path coefficient of the influence of business risk on financial performance of -0.224 can be interpreted that any increase in business risk of 1 rupiah will result in a decrease in financial performance of $-0,224$ rupiah.

The theoretical implication of this empirical is that increasing business risk will reduce financial performance. The findings of this study support the trade off theory (Modigliani and Miller, 1963) saying that increasing business risk will reduce profitability, because the increase in risk along with rising corporate operating costs will have an impact on decreasing operating income. The findings of this study support the research of Adi et al. (2013), Chukwunweike et al. (2014) found that business risk had a significant and negative effect on financial performance. The journey of a corporate's life is always faced with uncertainty called business risk. Keown et al. (1999: 494-496) say that business risk is the uncertainty or deviation of income before interest and taxes, and also the risks contained in the financing used.

\subsubsection{The Effect of Business Risk on Corporate Value}

Business risk (Y2) has a significant effect on corporate value (Y4), the path coefficient value is -0.102 ; CR value $6.00^{*}$; at the level of $\mathrm{P}=0.05$. The test results show enough empirical evidence to accept the hypothesis that "Business risk has a significant effect on corporate value", so hypothesis 9 is accepted. The results of statistical evidence show a negative and significant path coefficient. The negative path coefficient means that increasing business risk will reduce the value of the corporate. The path coefficient of the influence of business risk on the corporate value of -0.102 can be interpreted that any increase in business risk of 1 rupiah will result in a decrease in the value of the corporate of $-0,102$ rupiah.

The theoretical implication of this empirical is that increasing business risk will reduce the value of the corporate. This can occur because business risk is an uncertainty or income distortion. If the higher the uncertainty of income the corporate will obtain, then the market will underestimate the corporate's shares. The findings of this study support the leverage irrelevance theory (Modigliani and Miller, 1958) saying that the rate of return on investment (cash flow) and risk determine the value of the corporate. "In a perfect capital market, the total value of the corporate is the same as the market value of the total cash flow generated by the assets and is not affected by the choice of capital structure", in the sense that investment decisions in assets and asset use activities will generate cash inflows (profits) that affect the financial performance and value of the corporate, as well as the risk of uncertainty generated cash flow will determine the financial performance and value of the corporate.

The findings of this study do not support the research of Asiri and Hameed (2014) finding that business risk has a significant and positive effect on corporate value. The empirical implication is that increasing business risk will increase the value of the corporate. This happens, if investors expect a high rate of return by raising the corporate's stock price to offset the high risk. Theoretical and empirical explanations so far have shown that business risk has positive and negative impacts on corporate value.

\subsubsection{The Effect of Financial Performance on Corporate Value}

Financial performance (Y3) has a significant effect on corporate value (Y4), path coefficient value is 0.783 ; CR value 21.16* greater than 1.96; at the level $\mathrm{P}=0.05$ (table 3). The test results show enough empirical evidence to accept the hypothesis that "Financial performance has a significant effect on corporate value", so hypothesis 10 is accepted. The results of statistical evidence show a positive and significant path coefficient. Positive path coefficient, means an increase in financial performance will increase the value of the corporate. The path coefficient of influence of financial performance on corporate value of 0.783 can be interpreted that every increase in financial performance of 1 rupiah will result in an increase in corporate value of 0.783 rupiah. The theoretical implication of this empirical study is that improving financial performance will increase corporate value.

The findings of this study support the cash flow signaling hypothesis and permanent earnings hypothesis (Lintner, 1956); (Marsh and Merton, 1987) states that high profitability indicates high financial performance, and is a signal that the corporate has good quality control and performance and better future prospects. Irrelevance theory (Modigliani and Miller, 1958) explains that investment decisions and asset use activities determine performance and impact on corporate value. High profitability affects the corporate's financial flexibility, so the corporate is able to pay dividends to shareholders.

The corporate will get a positive assessment by the capital market, and raise its share price. The profitability obtained will largely determine a corporate's sustainable life, and the corporate will grow depending on one of them additional capital from the profits. The ability of the corporate to find profits will determine the ability to provide funds to finance the corporate's growth and dividends for the owner, eventually the owner's wealth 
increases.

Many investors are interested in buying shares from high-performing companies, the more that will buy, the price will rise (law of demand and supply), the opposite will happen if the corporate is low-performing. Ghosh and Arijit (2008) explain that financial performance has a positive impact on corporate value. Increased profits give a signal that the corporate's control and operations are better, so it has an impact on increasing the value of equity. The findings of this study support the research findings of Ghosh and Arijit (2008), Adi et al. (2013), Asiri and Hameed (2014) found that financial performance had a significant and positive effect on corporate value. The theoretical implication of the empirical study is that improving financial performance will increase corporate value. The ability of the corporate to generate profits will determine the ability to provide funds to finance the corporate's growth and dividends for the owner, eventually the owner's wealth increases. Many investors are interested in buying shares from high-performing companies, the more that will buy, the price will rise (the law of demand and supply), the opposite will happen if the corporate is low-performing.

\section{Conclusions}

The findings of this study is the asset usage activities has a significant negative effect on capital structure. The theoretical implication of this empirical study is that increasing the activity of using assets decreases the capital structure. This can happen because an increase in net sales findings shows that the corporate is operating effectively, so that it can accelerate cash receipts. Fast cash returns make available funds available for reinvestment and reduce debt and interest costs.

The asset usage activities has a significant negative on business risk. The theoretical implication of this empirical study is that increasing the activity of using assets will reduce business risk. This can happen because an increase in net sales results shows that the corporate is operating effectively, so that it can accelerate cash receipts. Fast cash returns make available funds available for reinvestment and reduce debt and interest costs

The asset usage activities has a significant positive effect on financial performance. The use of funds must be done efficiently and effectively in order to increase maximum profits. The function of the use of funds includes planning and controlling the use of assets, both in current assets and fixed assets, and the allocation of funds embedded in each element of the asset is not too small in number so that it can disrupt business liquidity and continuity, and other parties are not too large in number causing unemployment fund. A corporate that operates on high activity means that no assets are unemployed so that the efficient use of assets results in a decrease in managerial policy costs and increases corporate profitability.

The asset usage activities has a significant positive effect on corporate value. The theoretical implication of this empirical study is that an increase in asset use activities will increase corporate value. This can happen because an increase in net sales shows that the corporate is operating effectively, so that it can accelerate cash receipts. Fast cash returns make the amount of funds available to reinvest and make a profit and add value to the corporate.

The capital structure has a significant positive effect on business risk. This can happen, because debt in the capital structure has interest costs that will increase the risk of the corporate's business. If the debt is higher the interest costs will also rise and have an impact on decreasing profits and increasing the risk of failure if it fails to pay debts.

The capital structure has a significant negative effect on financial performance. The capital structure has a significantly positive on corporate value. The findings of this study support the pecking order theory (Myers and Majluf, 1984) that if companies want to use external funding sources, they must choose debt before new equity, because debt is cheaper and less sensitive to asymmetric information, so that the capital market will react positively towards debt issuance and makes the corporate's stock price go up.

The business risk has a significant negative effect on financial performance. The business risk has a significant negative effect on corporate value. The findings of this study support the leverage irrelevance theory (Modigliani and Miller, 1958) saying that the rate of return on investment (cash flow) and risk determine the value of the corporate. "In a perfect capital market, the total value of the corporate is the same as the market value of the total cash flow generated by the assets and is not affected by the choice of capital structure", in the sense that investment decisions in assets and asset use activities will generate cash inflows (profits) that affect the financial performance and value of the corporate, as well as the risk of uncertainty generated cash flow will determine the financial performance and value of the corporate.

Financial performance has a significantly positive effect on corporate value. The findings of this study support the cash flow signaling hypothesis and permanent earnings hypothesis (Lintner, 1956); (Marsh and Merton, 1987) states that high profitability indicates high financial performance, and is a signal that the corporate has good quality control and performance and better future prospects. Irrelevance theory (Modigliani and Miller, 1958) explains that investment decisions and asset use activities determine performance and impact on corporate value. High profitability affects the corporate's financial flexibility, so the corporate is able to pay dividends to shareholders. The study concludes that asset usage activities can determine the capital structure, 
business risk, financial performance and corporate value. Therefore, the corporate's management and financial analysts can examine the asset usage activities and capital structure, busines risk and financial performance to predict the future value of the corporate.

\section{Recommendation}

Based on the description and discussion of the findings that have been done, then the conclusions of this study are as follows:

Advice for Advanced Research. Based on the limitations of this study, the suggestion of this research for further research is as follows: Future research can add other variables that have not been included in this research model, to obtain a more comprehensive research model. Integrate financial statement data and other relevant information to overcome the limitations of historical data in the financial statements. Further research can be done elsewhere in a longer time, or replace other research objects.

Recommendation for Companies in Indonesia Stock Exchange. For companies in Indonesia Stock Exchange and investors, the findings of this research are expected to be useful input in decision making or financing policy of a corporate. Management should consider the corporate's business risk and asset-utilization activities. Further practically for companies in Indonesia Stock Exchange and investors, can be suggested as follows:

Increase asset utilization activities to enable the corporate to become more effective and efficient in its operations, thereby reducing the use of interest-bearing debt, and resulting in improved financial performance as well as corporate value. Use debt at the lowest possible cost level in order to increase profits. Maintain and improve financial performance, because financial performance is a very powerful variable in determining the value of the corporate. Because investors will appreciate the shares of companies that have high financial performance at the highest price. It should in financial report data and other relevant information for the purposes of analysis in order to produce a more precise prediction. To overcome the limitations of financial statements, because the financial statement data is historical data or past data. In the event of an error in disclosure in the financial statements, it will result in a less precise prediction finding.

\section{References}

Adi, Tri Wahyu. Suhadak. Siti Ragil Handayani and Sri Mangesti Rahayu. (2013). The Influence of governance and capital structure on risk, financial performance and corporate value: a study on the mining corporate listed in Indonesia Stock Exchange in 2009-2012. European Journal of Business and Management, 5(29): 200-217.

Akorsu, Patrick Kwashie. (2014). Testing the pecking order and signalling theories for financial institutions in Ghana. Research Journal of Finance and Accounting, 5(16): 77-83.

Almajali, Y. A. Alamro, S. H. and Al-Soub, Y. Z. (2012). Factors affecting the financial performance of Jordanian insurance companies listed at Amman stock exchange. Journal of Management Research, 4 (2): 266-289.

Anake, Atseye Fidelis. Obim, Edim Ndifon and Eke, Felix Awara. (2014). Determinants of financial structure: Evidence from Nigerian quoted corporates. Research Journal of Finance and Accounting, 5 (16): 53-66.

Asaduzzaman, Md. Chowdhury, Tabassum. (2014). Effect of working capital management on corporate profitability: Empirical evidence from textiles Industri of Bangladesh. Research Journal of Finance and Accounting, 5(8): 175-184.

Asiri, Batool K. and Hameed, Salwa A. (2014). Financial ratios and corporate's value in the Bahrain bourse. Research Journal of Finance and Accounting, 5 (7) :1-9.

Barakat, Abdallah. (2014). The impact of financial structure, financial leverage and profitability on industrial companies shares value (applied study on a sample of Saudi industrial companies). Research Journal of Finance and Accounting, 5 (1): 55-66.

Bokhari, Haseeb Wadood and Khan, Muhammad Arif. (2013). The impact of capital structure on corporate's performance a case of financial sector of Pakistan. European Journal of Business and Management, 5 (31): 111-137.

Chowdhury, A and S.P Chowdhury. (2010). Impact of capital structure on corporate ${ }^{\text {ee }}$ value: Evidence from Bangladesh. Business and Ecomic Horizon (BEH), 3 (3): 111-122.

Chukwunweike, Ehiedu Victor and Osiegbu, Patrick I. (2014). Capital structure and performance evaluation in manufacturing sector: A case study of selected quoted companies in the Nigeria stock exchange (NSE). Research Journal of Finance and Accounting, 5 (6): 35-40.

Gathogo, George, and Ragui, Mary. (2014). Capital structure of kenyan corporates: What determines it?. Research Journal of Finance and Accounting, 5(5): 118-125.

Ghalandari, Kamal. (2013). The moderating effects of growth opportunities on the relationship between capital structure and dividend policy and ownership structure with corporate value in Iran: Case study of Tehran Securities exchange. Research Journal of Applied Sciences, Engineering and Techlogy, 5 (4): 1424-1431. 
Ghosh, Surabah and Arijit Ghosh. (2008). Do leverage, dividen policy, profitability influence future value of corporate? Evidence from India. Electronic copy available at: http://ssrn.com/abstract=1158251.

Gopal, CAC. Rama. (2009). Accounting for Managers. New Age International (P) Ltd. Publishers. New Delhi.

Hanafi, Mamduh. M. (2010). Financial Management. First Edition of Faculty of Economics University Yogyakarta.

Isaac, Lambe. (2014). capital structure and corporate's market value in Nigeria. Research Journal of Finance and Accounting, 5 (12): 16-31.

Jang, S. and Park, K. (2011). Inter-relationship between corporate growth and profitability. International Journal of Hospitality Management, 30(3): 1027-1035.

Kamaludin dan Indriani, Rini. (2012). Financial Management "Basic Concepts and Implementation" Revised Edition Cv. Mandar Maju. Bandung.

Keown, Arthur J. Scott, David F, Jr.Martin John D. Petty, J. William, Interpretation by Djakman, Chaerul D. Fundamentals of Financial Management. (1999). Salemba Empat. Jakarta. Simon and Schuster (Asia) Pte.Ltd.Prentice-Hall Inc.

Lintner, John. (1956). Distribution of incomes of corporations among dividens, retained earnings, and taxes. Papers and Proceedings of the Sixty-eighth. Annual Meeting of the American Ecomic Association. The American Economic Review, 46 (2): 97-113.

Marobhe, Mutaju Isaack. (2014). The influence of capital structure on the performance of manufacturing companies: empirical evidence from listed companies in East Africa. Research Journal of Finance and Accounting, 5 (4): 92-100.

Marsh, T.A, and Merton, R.C. (1987). Dividend Behavior for the aggregate stock market. The Journal of Business. 60 (1): 1- 40.

Modigliani, Franco, and Miller, Merton H. (1958). The cost of capital, finance and the theory of investment. American Economic Review, 48(48): 261-297.

Modigliani, Franco, and Miller, Merton H. (1961). Dividend policy, growth, and the valuation of shares. The Journal of Business, 34 (4) : 411-433.

Modigliani, Franco, and Miller, Merton H. (1963). income taxes and the cost of capital: a correction. American Economic Review, 53(3): 433-443.

Myers, Stewart C. (1977). Determinants of borrowing. Journal of Financial Economics, 5(2): 147-175.

Myers, Stewart C. (1984). The capital structure puzzle. Paper and Proceedings, Forty-Second Annual Meeting, American Finance Association, San Fransisco, CA, The Journal of Finance, 39 (3): 575-592.

Myers, S. C. and Majluf, N. S. (1984). financing and investment decisions when corporates have information that investors don't have. Journal of Financial Economics, 13(2): 187-222.

Ogebe, Patrick; Ogebe, Joseph and Alewi, Kemi. (2013). Capital structure and corporates performance in Nigeria. St. Augustine College of Education, Project TIME Akoka Lagos. pp. 1-23. Electronic copy available at: $h t t p: / / s s r n . c o m / a b s t r a c t=2266916$.

Ogbulu, Onyemachi Maxwell. Emeni, Francis Kehinde. (2012). Capital structure and corporate value: empirical evidence from Nigeria. International Journal of Business and Social Scienc, 3 (19): 252-261.

Oluwagbemiga, Oyerogba Ezekiel. (2013). Perceived relationship between capital structure and corporate value in the Kenyan listed companies. Research Journal of Finance and Accounting, 4 (19): 157-165.

Omondi, Maleya M. Muturi, Willy. (2013). Factors affecting the financial performance of listed companies at the Nairobi securities exchange in Kenya. Research Journal of Finance and Accounting, 4 (15): 99-104.

Oppong-Boakye, Paul Kofi. Appiah, Kingsley Opoku. Afolabi,James Konadu. (2013). Determinants of capital structure: evidence from Ghanaian corporates. Research Journa of Finance and Accounting, 4 (4): 44-52.

Pakpahan, Rosma (2010) Pengaruh Faktor-Faktor Fundamental Perusahaan dan kebijakan Dividen Terhadap Nilai Perusahaan, Jurnal Ekonomi, Keuangan, Perbankan dan Akuntansi, 2 (2): 211 - 227.

Poddar, Neha. and Mittal, Manish (2014). Capital structure determinants of steel companies in India: a panel data analysis. GALAXY International Interdisciplinary Research Journal, 2 (1): 144-158.

Pontoh, Winston. Ilat, Ventje. (2013). Determinant capital structure and profitability impact (study of listed corporate in Indonesian stock exchange). Research Journal of Finance and Accounting, 4 (15): 43-49.

Raheman, Abdul and Nasr, Mohamed. (2007). Working capital management and profitability - Case of Pakistani Corporates. International Review of Business Research Papers. 3 (1): 279 - 300.

Ross, Stephen A. (1977). The determination of financial structure: the incentive signaling approach. Bell Journal of Economics, 8 (1): 23-40.

Saeed, Rashid. Munir, Hafiza Mubeen. Lodhi, Rab Nawaz., Riaz, Ayesha. Iqbal, Amber. (2014). Capital structure and its determinants: empirical evidence from Pakistan's pharmaceutical corporates. J. Basic. Appl. Sci. Res. 4 (2):115-125.

Siahaan, Uke Marius., Suhadak., Siti Ragil Handayani and Solimun. (2014). The influence of corporate size and capital structure towards liquidity, performance and corporate value, for large and small group companies. 
European Journal of Business and Management, 6 (18): 148-156.

Umar, Muhammad. Tanveer, Zaighum. Aslam, Saeed. Sajid, Muhammad. (2012). Impact of Capital Structure on

Corporates' Financial Performance: Evidence from Pakistan. Research Journal of Finance and Accounting, 3 (9):1-12. 